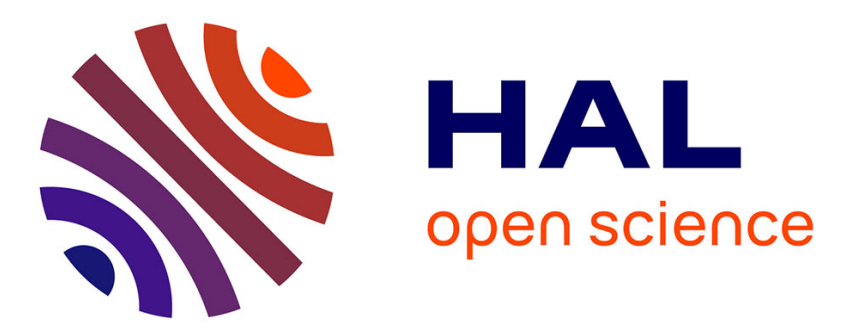

\title{
Politico-ritual variations on the Assamese fringes: do social systems exist? \\ Philippe Ramirez
}

\section{To cite this version:}

Philippe Ramirez. Politico-ritual variations on the Assamese fringes: do social systems exist?. F. Robinne \& M. Sadan. Social dynamics in the Highlands of Southeast Asia: Reconsidering political systems of Highland Burma, Brill, pp.91-107, 2007, 12819214679781281921468 . hal-00763959

\section{HAL Id: hal-00763959 \\ https://hal.science/hal-00763959}

Submitted on 12 Dec 2012

HAL is a multi-disciplinary open access archive for the deposit and dissemination of scientific research documents, whether they are published or not. The documents may come from teaching and research institutions in France or abroad, or from public or private research centers.
L'archive ouverte pluridisciplinaire $\mathbf{H A L}$, est destinée au dépôt et à la diffusion de documents scientifiques de niveau recherche, publiés ou non, émanant des établissements d'enseignement et de recherche français ou étrangers, des laboratoires publics ou privés. 


\title{
Politico-ritual variations on the Assamese fringes: do social systems exist? $^{1}$
}

\author{
Philippe Ramirez \\ [in Social dynamics in the Highlands of Southeast Asia : Reconsidering political systems of \\ Highland Burma. F. Robinne ; M. Sadan (Eds) -- Leiden : Brill, 2007, p.91-107. Pages may differ \\ in the final publication]
}

For its vast cultural diversity and the multiple interactions among its human groups, Northeast India, i.e. Assam and its adjoining areas, may be described as a paradise for the anthropologist. For the same reasons, however, when interpretations and hypotheses have to be considered, when some "order" has to be envisioned, paradise may turn into a hell. The discrepancies between ethnic labels, social patterns and cultural features, the internal differentiations within groups, the overlapping of political and ritual models, all make the social scientist doubt whether any assertion can be put forth, whether any social system exists at all. The recent flowering of ethnic politics in the region adds an additional dimension which doesn't make the task easier. As a matter of fact, the anthropological complexity that characterises Northeast India pertains to a wider Southeast Asian area, which also covers Northern Burma. So it is natural that PSHB is called upon by anyone attempting to find coherence in the great anthropological maelstrom of present-day Assam.

The scepticism of Leach, which inspired him to the general idea of dissociation between political systems and "tribes", has the great merit of conjuring essentialism, which always threatens the anthropologist. Essentialism is a pervasive trend in the times of ethnic revivalism in which we are living, and particularly so in present-day Northeast India. The area experiences multiple identity claims, the discourses as well as consequences of which may be usefully analysed with the tools provided in PSHB. The discursive essentialism of ethnic movements sometimes runs up against such obvious cultural disparities on the ground $\square$ that even hard-liners have to admit their significance. Ethnicism assumes a perfect correlation between a territory, language and socio-political system. As is obvious to all, correlations with this degree of adequacy are rarely realised in Assam. Nevertheless, one cannot reject ethnic categories too easily only on the pretext that they do not correspond to actual cultural or social entities. Every contemporary anthropologist would agree that is not cultural homogeneity that makes an "ethnic group" but a perception. They are representations 
through which people feel they belong to a coherent and perennial entity. In this sense, the Assamese ethnic groups, or "tribes", as they are called and call themselves, are real. Thus remains the task of analysing the competing articulations of identity discourses and the "reality" of other domains, a task which was central in PSHB.

I will briefly present three cases taken from Tibeto-Burmese speaking people living at the fringes between hills and plains in Central Assam. These cases are drawn from research that focuses mainly on the historical and anthropological foundations of ritual geography in an area that, before the British Raj, was alternatively or conjointly under the political authority of three main states: the Ahom, the Jaintiya and the Dimasa (or "Kachari"). Some historical background is necessary before proceeding to the anthropological data. From the thirteenth century onwards, a number of warriors of Tai origin, the Ahom, gradually conquered the lowlands of the Brahmaputra valley. There they became acculturated by the former elite, who were Hindu by religion and Assamese-speaking. In Central Assam they faced competition from two hill-based states: the Jaintiya kingdom, which was culturally close to the Khasi, centred on the Eastern Meghalaya plateau and whose authority extended far below the foothills; the Dimasa kingdom, which till the sixteenth century controlled the greater part of south-central Assam before slowly receding towards the southern hills of present-day North Cachar district. The precious Ahom chronicles, the burañjis, provide valuable testimonies on the relations between the rising Ahom power and the existing states. ${ }^{2}$ They also give several indications on a number of people and chiefs who lived on the southern foothills of the Brahmaputra valley and whose allegiance gradually shifted from the Jaintiya and Dimasa to the Ahom. Thus, on the fringes of its dominion, the Ahom sovereign (swargadeo) recognised a number of petty kings, the rāja povāli, who begged for his protection and were required to assist him in war. These chiefs, significantly called dāntiyāliya rājāa ("kings of the margins"), generally controlled the lower portions of the routes linking the hills to the plains via a number of marts at the bottom. These small dominions played a "bridge and buffer role", which has to be kept in mind when considering the shaping of local cultures and identities. ${ }^{3}$

The first example that I will explore pertains to the people who call themselves Dimasa ("Sons of the large water"). Numbering around 100,000, they speak a Bodo-Garo language and live in the hills bridging Meghalaya and Nagaland. In British times they fell under the label "Kachari", which covered a fair portion of the Tibeto-Burmese speaking groups of the 
plains, including the people who today refer to themselves as Bodo. These Dimasa display a kind of anthropological strangeness in their descent system which is dual, combining male clans and female clans respectively passed on by men and women. Dimasa conceive of themselves as the descendants of rulers and subjects of the Dimasa kingdom. Ahom chronicles attest the existence of "Timisa kings" (khun timis $\bar{a})^{4}$, who ruled over a large area of Middle Assam, initially from Dimapur on the Western foothills of present-day Nagaland. They were driven by the Ahom towards the south to their present habitat where in 1540 they founded the Hedamba kingdom. Despite the scarcity of data on this kingdom, the archaeological vestiges in successive capitals (present-day Dimapur and Maibong) indicate a fair level of economic strength and centralisation. From at least the eighteenth century, the kings and the elite went through a process of Hinduization, apparently under the influence of the Bengali brahmans attached to the court. Following the final invasion of the area by the Ahom in 1745, the kings and part of the commoners settled further south in the plains of Cachar. Culturally speaking, present-day Cachar Dimasa can hardly be distinguished from the Bengali majority and they seem to make little attempt politically to assert their identity. In the hills, however, Dimasa remained demographically dominant whilst cohabiting with Hmar-Kukis and Zemi Nagas. As a scheduled tribe, they obtained the creation of an "autonomous council" in 1952 and of an autonomous district (NC Hills) in 1972, where they benefit from special reservations.

In some ways, Dimasa people of North Cachar Hills face few problems when dealing with their identity. They share a fairly high linguistic and cultural homogeneity, all claiming their link with the former Hedamba kingdom. In comparison to their neighbours, their society can be described as a "sealed society". The status of Dimasa is strictly acquired by descent: a Dimasa is defined by his descent from both a male clan and a female clan, adoption within a Dimasa clan is impossible, and union with a non-Dimasa forbidden. In the latter case, such an act exposes the whole community to impurity (gushu) and it generally results in excommunication. Nowadays, Dimasa girls may on rare occasions be allowed by their patriclan to marry a foreigner after being purified in their clan sanctuary, but even in this case, any offspring will be denied Dimasa status. Finally, under the special provisions conceded by the Indian State, matrimonial affairs, like other "customary" affairs and land issues, legally fall 
within the authority of the autonomous district council. This judiciary autonomy reinforces the "exclusive identity" of Dimasa.

This does not mean that the internal order of the society is the object of a consensus among Dimasa. Put simply, despite the harsh protective measures enforced towards external influences, Dimasa society has indeed recently experienced dramatic changes in its cultural, economic and demographic features. Among others, the decline of shifting agriculture (jhum) as the main source of revenue and the shift from the villages to the towns have deeply transformed the mode of living and the human geography of the area. These changes have necessarily resulted in inconsistencies that have provoked debates between conflicting views on "tradition".

A few years ago, the autonomous council was asked to rule on the exact meaning of the word which refers to the main Dimasa ritual institution, the daikho, which for the moment we will only define as a "worship circle". The debate pertained to the concrete case of a priest attached to a daikho who had planned to move his home to another location, and intended to shift the place of worship as well. Some of the follower lineages strongly objected to this. They resorted to etymology, postulating that "dai-kho" was in fact "mdai-kho", "god-abode", or the "house of god", and that consequently it could not be displaced; the priest on his side argued that a daikho was simply a "worship spot", independent of any locality, and thus the offerings could be made anywhere. ${ }^{5}$

So what is a daikho? The question is central to any attempt to describe the ritual institutions of the Dimasa and has tormented at least one anthropologist before me. Relying on the data she collected in the seventies in Northern North Cachar, Danda stated that the whole of Dimasa country is under the authority of "area-gods" who have "non-structured sanctuaries" in different localities, called daikho. ${ }^{6}$ The area-god controls the life of the villagers who live in its area. However, Danda noted several elements which pointed towards clanic features of the daikho: in some localities, certain clans claimed to be affiliated to another daikho than the local one, worshipping the first one, the second or both. She concluded that the "daikho gods" were formerly clan-gods but that due to migrations, they became area-gods. ${ }^{7}$

The elements I collected in Southern North Cachar in 2002 differ significantly from those of Danda, but, as we will see shortly, they pose the same problems of interpretation. I need to 94 
say first that I came across two particular types of hurdles. First, the indigenous descriptions of the daikho vary greatly from one informant to the other; second, the main functionary of the institution, the jonthai priest, strictly avoids all kind of impurities, including the contact with foreigners, i.e. all "non-Dimasa". So the information one can obtain originates only from laymen.

All informants described the daikho as a spot where collective worship of local deities was held either on a clan-basis or on a pan-Dimasa basis. People are supposed to gather regularly in a daikho with their agnates to sacrifice to their tutelary deity and, should any disaster affect the Dimasa area, such sacrifices would be held simultaneously in all daikho. It is not clear whether the daikho corresponds to an ancient administrative unit, but everybody attributes the institution to the ancient kings. Furthermore, although the most commonly given etymology of the term is "house of god", i.e. sanctuary/temple, some translate it as "container of fines", the place where in ancient times the judiciary fines were collected. According to these informants, the offenders were fined and purified only in the daikho to which they were attached.

The Dimasa land is said to be divided into twelve daikho, each presided over by a god and under the responsibility of a priest, the jonthai, selected from a particular clan and who cannot in any case leave his post. The activities of the jonthai are monitored at the centre by two religious officers, the Great jonthai, jonthaima, and the purificator, gisia, who are themselves appointed by the council of the forty Dimasa male clans, the calis. At first glance, therefore, the daikho system as described by the Dimasa may look well codified, coherent and in tune with the ancient political context.

However, beyond these general principles, all kinds of detailed descriptions may be heard, and, as one tries to go more deeply into the subject, the first impression of coherence gives way to a feeling of true confusion. For instance, a seemingly simple question such as "Who appoints the jonthai?" gets several different answers: some say they are appointed by the great priests (jonthaima-gisia), other that they are chosen by the daikho followers, sometimes by divination, sometimes without, or that they inherit the function from their father. Similarly, (but this is more common in India) an inquiry about the list of the twelve daikho do not generally go beyond the same two or three names. ${ }^{8}$ One wonders, then, if it is possible 
at all to draft a general sketch of the system, to clear up a minimum number of common pratices, or even to draw a simple map of the daikhos.

More troublesome still is the absence of certainty concerning the relationships between daikho, gods, clans and territories. Although daikho worship displays many clanic features, the Dimasa seem not to be sure whether the first criterion for affiliation is the clan or the residence. The touchstone of the problem is obviously migration: what happen if a family migrates far from the daikho it used to attend? Some insist that it would have to perform in the original daikho, while others assert that it would attend the nearest daikho. This ambiguity possibly reflects the equal importance of the principles of descent and residence in present-day Dimasa society. I am not convinced that, as Danda suggested, clan affiliation gives way to locality affiliation and that clan-gods became locality-gods. Dimasa social structure undoubtedly went through major transformations, especially after the disappearance of the local State and its centralising dynamics; this is a subject too broad to be elaborated upon here. Nevertheless, the relationship between descent and residence is always a complex one, and all the more so when one considers its ritual features. In any clanic society, local gods may be adopted by immigrating clans, thus becoming clan-gods, or clans may bring in their own "portable" tutelary god and "settle" it in their new locality. A right-holder clan always develops an osmotic connection with its locality so that the locality gets identified with a clan and a clan with a locality. ${ }^{9}$

Thus, we may remark that although Dimasa make both the clans and the daikho the two main pillars of their society, they feel uneasy when asked to account verbally for the relationships between the two, because, unavoidably, contradictions arise. I suggest that most of these contradictions are due to the fact that the anthropologist, trying to crosscheck discourses with "real facts", generally confounds at least two, if not three domains of facts, or logics: the domain of identity discourse, the domain of general rules and the domain of practice. Each domain has its own coherence which cannot be simply translated to the others. When Dimasa define their society as having forty patriclans and twelve daikhos, it should not be taken as an assertion of the actual number of existing clans and daikhos. Similarly, if it is found that at the larger scale, the clan is the organising principle of daikho worship, it does not rule out the possibility that lineages within a clan will attend different daikhos on a territorial basis. 
As a matter of fact, it seems that the actual practices reflect all the possible arrangements of clanic and territorial worship. As an illustration, one very peculiar case may be described, that of the ideal village of Semkhor, which stands somehow outside the daikho complex, but which, paradoxically, helps us to understand its nature. Semkhor, a remote locality on the fringe of the Naga hills, is a strictly sealed village, multi-clanic and fully endogamous, very timid towards foreigners; these features make it a kind of microcosm of Dimasa society, a picture which is confirmed by the fact that, according to some Dimasa, within its limits seven salt wells are to be found, which corresponds to the seven original Dimasa clans. ${ }^{10}$ This suggests the existence of former clanic monopolies over salt and maybe a central daikho. Semkhor has adopted a ritual formula that enables it to combine the principles of clan and territory: each clan worships its own tutelary deity in a specific spot outside the village. ${ }^{11} \mathrm{I}$ think this peculiarity is far more than idiosyncratic. In a certain way, it is the strict ritual separation between clans that constitutes the village unity; a paradigm that suggests that it is not in the strict adherence to a unique set of norms that the coherence of the daikho complex may be found.

Thus, the apparent uncertainties of Dimasa discourse on the ritual institutions neither point to deculturation (to a "detribalisation") nor sustain the idea of a chaotic, non-structured reality. I have no doubt that the Dimasa, when the time arises, know exactly what they have to do, and that rules in the true sense preside over the practices. What needs to be underlined in the light of this data is that the general description $\square$ and possibly perception as well $\square$ of the institution by the actors themselves gives little clue to its operation. This is not to suggest, as Leach suggested in PSHB's 1964 introduction, that world-view and practices are fully dissociated. They are certainly articulated by a "missing link" which substance may be searched for in the historical transformations which followed the vanishing of the Hedamba state: Dimasa would still view their society as a centralised clanic state.

In comparison with the Dimasa, the second society I would like to consider displays almost antinomic features. The 400,000 Karbi, scattered in the hills and plains between the Meghalaya plateau and the Naga hills, do not possess very deep and corporate clans. They have apparently developed no centralised political institution,-except the Karbi-Anglong autonomous district council (1952) which administers the hilly section of their territory. They 
are divided between at least three cultural areas. And although the quality of Karbi is theoretically based on the belonging to a Karbi clan, outsiders may be adopted through a "purification" rite. If they did not speak relatively similar languages, all part of the KukiNaga family, the unity of the Karbi would seem to be almost purely \ethnic $\square$, i.e. widely selfascriptive. In other words, compared to the $\llbracket$ sealed society $\square$ of the Dimasa, Karbi society could be qualified as an $\lceil$ open society $\square$

The Karbi were made famous by a monograph written by Edward Stack in the early twentieth century on "the Mikirs", as they were called by the British and the Ahom. ${ }^{12}$ The "Mikirs", as the Karbi today, were divided into five clans which are represented in all Karbi inhabited areas and which have little other role than fixing the exogamic rules. Politically, three types local government are found among the Karbi:

The Karbi of the plains, called Dumrali by the Hill Karbi, live outside Karbi Anglong district, within Assamese-dominated or multi-ethnic settlements. As many other plains tribes, they do not fall under the Sixth Schedule of the Indian constitution which provides the scheduled tribes with the capacity to run an "autonomous council" of their own. So, among the plains Karbi, there exists no traditional authority above the hereditary village chief (bangthai), who is stricto sensu a ceremonial chief but who also often assumes the charge of gā̃u burā, the usual official village chief in Northeast India.

In Karbi-Anglong district, the autonomous council appoints village chiefs (sarthe) in all areas and deals with land as well as customary issues. ${ }^{13}$ In the eastern half of the district, the system is relatively simple, with no intermediate levels. The old council of village elders (me), which is said to have been formerly the real seat of authority, seems now to be in decay.

In western Karbi-Anglong however, formerly under the sphere of influence of the Jaintiya kings, there remains above the usual village chiefs a sophisticated institution which the Karbi call the lindok system, by reference to its head functionaries, the lindok. As in the case of the daikho among the Dimasa, the descriptions of the lindok system by the Karbi vary greatly and often look incoherent at first sight. As a matter of fact, the rules differ from one place to another, but even within a single area the perceptions differ, particularly in the relationships between functions and territories as well as in the territorial setting itself. Let us focus now on what happens in this particular area.

Every Karbi agrees on the existence of three main territorial divisions, which are always 
listed in the same order of precedence: Rongkhang, Chinthong and Amri. Each division is governed by a pinpomar, a council of pinpo, who are representatives appointed by their peers from a number of constituencies. Within the pinpomar, representatives of a constituency are headed by a lindokpo, who is endowed with several royal aspects and referred to as a recho, i.e. raja. A very peculiar feature of this system is that during their tenure, the pinpo come to live in a "capital town" (rongbong), a specific isolated locality which is internally structured into wards corresponding to each constituency and centred round a sacred enclosure. The pinpomar appoints local chiefs, the habe, who are each in charge of several villages: their prime responsibility is to supervise rituals and settle cases pertaining to customary laws, i.e. mainly matrimonial affairs. Habe regularly refer to the pinpomar, which thus acts as a paramount court for the customary affairs. So at first sight, the lindok system appears to be a well structured "tribal state" with clear-cut representation and decision processes as well as territorial attributions.

However, as in the Dimasa case, the geographical structure of the institution is much more difficult to discern. It is not a surprise that ordinary villagers are unable to describe it in all its details: what proportion of British or French voters can clearly picture the structure of the local governments they are supposed to elect? Yet, one faces the same difficulties in making the various accounts given by the functionaries themselves coincide. The number of habe varies, the names of their territories vary, spatial groupings vary,-and so on. So, if at the most general level the system is described as structurally homogeneous and spatially continuous, when it comes down to the details it appears spatially discontinuous and incorporating a number of local peculiarities. In the Karbi case, centralisation does not involve levelling. Historical facts may account for some of the political discrepancies. Western Karbi-Anglong has remained under Jaintiya suzerainty long after the imposition of Ahom rule in the eastern part (seventeenth century). Later on, the east was more directly administered by the British than the west, which like other "primitive inhabited areas" was qualified as "excluded" or "partly-excluded" and not subject to tax settlement. On a more local scale, differences were numerous. Nevertheless, the heritage from different administrative regimes does not suffice to explain the gaps between representations and physical practical settings.

An even greater heterogeneity characterises the content of collective rituals, even in the 
lindok divisions. This may look striking, as one of the main functions of the lindok institution is to monitor these rituals. Rongker, the prosperity festival which is cited by all as the most important ritual, as "the" festival of the Karbi, is not associated with the same territorial levels and with the same type of deities in all localities. Literally, "Rong+ker" means "village+public worship". Stack described it as an annual village worship dedicated to two types of deities: firstly the "Great Hill" (Inglongpi), the god of the hill where the village stood; second, the "Hundred Gods" (Arnam pharo), which Stack interpreted as a collective term. Both were asked to let villagers use their territory during the year in exchange for sacrifice. In exceptional cases, like attacks by tigers, Great Rongker (Rongkerpi) may be organised on a mauja basis (several villages). ${ }^{14}$ A Karbi writer I interviewed in the district headquarters recently gave me a quite similar account: during the annual Rongker, the village propitiates first the three "great gods" (Hemphu the creator, Mukrang, his first follower and brother-in-law, Rasinya, Hemphu's sister) and then the "local" ones. On a less regular basis, groups of villages, belonging or not to the same territory, may perform Vophong Rongker for their own benefit. Another intellectual from the same area stated that annual Rongker was held conjointly by several villages. Other Karbi of all extractions held varying views, including the inexistence of a territorial basis for this ritual. In Chinthong division, functionaries in charge of the management of all local ritual asserted that no village Rongker took place in their area, but only a general Rongker organised at the division level. Finally, the plains Karbi of Kamrup (Guwahati area) do not perform Rongker at all, their main annual collective ritual being Dehal püjāa, addressed to Tamlong alias Buda Gohāi. In Hindu Assamese terms this would mean a "temple worship" (deval püjā) in honour of Siva.

It is even difficult to understand if the present Karbi conceptualise something looking like local deities, to which this annual worship would be addressed and who would give us a clue on the Karbi symbolic landscape. Educated Karbi definitely seem to under-estimate these deities, in favour of non-localised encompassing "Great god(s)", particularly Hemphu, evoked with a mixture of Hindu and Christian tones. More generally, Karbi seemed puzzled by my questions about "local deities". Only twice did I obtain a definite statement that confirmed the existence of "area deities" (longri arnam) who were addressed to during Rongker. The general impression is that Rongker is definitely a collective ritual, that it is not clanic at all but territorial, but that according to localities it is held on different territorial 
levels and according to different procedures. Even in the western area, under the lindok regime, the sophistication of a central authority at the higher level does not imply that practices at lower levels are similar and tightly regulated, and it does not imply as well that inhabitants of a particular locality are aware of their neighbours' practices.

The rationale behind the lindok institution is not itself obvious. One could argue that it is a relic of a vanished political system, with no remaining coherence. It could also be seen as "artificially" maintained by the Karbi, as a virtual symbol of their unity, a sort of pastiche of a State. In this case, the lindok system would form a pure variant of Geertz's "theatre-state", which would have relinquished all concrete governmental functions, and a great part of its territorial rooting. ${ }^{15}$ I won't go so far, because several clues show that the lindok and habe still hold aspects of concrete power. In matrimonial affairs at least, it seems that they are still able to impose their decisions. As for the rituals, they still "send orders" to the local headmen when the time comes, asking them to start the performances. However, it is true that everything looks as if the main preoccupation of the apparatus is to ensure that, in the ritual domain, things are done, whatever the way they are done. Parallels can be drawn with what we have called above the Dimasa "identity discourse". Through the lindok system it is an ideal image of the "traditional" Karbi society that is enacted, however faithfully or not it reflects the actual practices.

While entertaining comparable representations on the ideal order of society, Dimasa and Karbi conceive the relationships between this internal order and the outer world in diametrically opposite ways. Where the Dimasa stem by birth from a matrix (the forty clans) that must be protected from the introduction of all external elements, Karbi internal order is a mould where external elements can be melted. Among Dimasa and Karbi the disorder implied by contact with the alien is dealt with through the same operation: purification (Dimasa: thar-ba, Karbi: thekal). ${ }^{16}$ However, purification, which in both cases restores order, does so in two opposite ways and thus brings forth opposite outcomes: the Dimasa purification aims solely towards the exclusion of the foreign substance, the pollution, be it in the case of polluted mourners or of polluted wrongdoers, who were formerly "purified" after being fined; the Karbi purification washes the foreign element of its alien-ness, thus enabling its integration. It may without too much risk be compared with a baptism. 
Karbi commonly assert that a Karbi is someone who believes in the supreme god Hemphu and who follows the rules instructed by him: so in principle anybody can become a Karbi. This idea is much more than a modern progressive slogan. The process, already mentioned by Stack one century ago, is quite common and I have documented a recent case of collective conversion from Garo to Karbi not far from Guwahati. ${ }^{17}$ A Garo village isolated among Karbi had difficulties finding matrimonial matches; so, by a simple act of collective purification and clan name attribution, all of its inhabitants became Karbi. Such a case is a clue to one of the several processes through which Karbi diversity - and in fact Assamese diversity - could historically have been established.

The set of rules that Hemphu instructed and that one has to follow as a Karbi is hardly detailed beyond the respect of clan exogamy. But it is the declaration that matters, much more than the content: for contemporary Karbi, the ultimate criterion is the creed in the rules. I cannot for the moment assess how ancient is this attitude, and how far its Christian tones have something to do with the conversion of a part of the Karbi to Christianism during the twentieth century. Nevertheless, such a model of identity building is not completely at odds with what seems to be an older model in Assam, and elsewhere in India, in which a group identity $\square$ ascribed identity at least $\square$ is determined not by certain cultural features but by the allegiance to a political authority or to a political order. In this case, cultural heterogeneity does not prevent coherence of the group in terms of identity or social relationships. However, the modern Karbi introduced a new dimension in the old model: not only cultural features but also political affiliations are secondary to the assertion of identity. Karbi are neither those who live in the autonomous district nor those who are governed by a peculiar set of institutions (e.g. the lindok system), they are all those who claim to be Karbi.

The Karbi identity model as proposed here may be particularly contrasted with the third case I will describe, which represents what I call the "old identity model". In such a model, externally or internally ascribed group identity was determined by political affiliation. For instance, at the advent of the British Raj, the Karbi of Eastern Meghalaya were identified as Bhoi. From a Khasi point of view, "Bhoi" referred to several linguistically distinct groups living at the Northern periphery of the Khasi-Jaintiya polities and whom the Khasi and Jaintiya chiefs claimed as their subjects. ${ }^{18}$ Among these groups fell those who today call themselves Lalung or Tiwa (c. 35, 000): they inhabit the northeastern corner of Meghalaya, 
speak a Bodo-Garo language, and display a matrilineal descent system, like their Jaintiya and Khasi neighbours. ${ }^{19}$ The present Tiwa do not identify with Bhoi but with a confederation of principalities at the margin of the hills and plains. The Ahom chronicles mention several petty kings on the southern fringe of the Brahmaputra valley who, in the eighteenth century, alternatively fought or paid allegiance either to the Jaintiya kings or to the Ahom, before finally being forced to submit by the Ahom. ${ }^{20}$ Ahom and Jaintiya kings entrusted them with the task of ensuring free access to the routes and markets linking the Jaintiya kingdom to the plains. The chronicles did not culturally qualify these chiefs, but the deorājō of Khala, Gobha, Neli and Sahari still exist today as symbolic rulers of the Tiwa. Deputies of each division within each kingdom annually visit their king and are re-appointed by receiving a turban. According to Tiwa traditions the four remaining kings were part of twelve deorāja who each ruled a division of the present Tiwa territory. ${ }^{21}$ Whether the different kings had a similar status in the past is not known, but the present ritual arrangements ascribe a senior position to the raja of Gobha. He is now considered as "the King of the Tiwas", and receives allegiance during a great annual fair (Jonbil melā) which gathers people together from the whole region. ${ }^{22}$

Most of the plains Tiwa speak Assamese and are patrilineal. They claim to have come from the hills to flee the imposition of matrilineality by the Jaintiya kings. Their religion shows as many features common with Hill Tiwa as with the Assamese Hindus. ${ }^{23}$ In fact, under the British and sometime after Independence, they were refered as "plains Lalungs". However, they now strongly reject the term Lalung, which they consider derogatory. Their economic condition and levels of literacy are higher than those of the hill people and their elite are very active in ethnic politics, so that they have now become the reference point of Tiwa-Lalung ideal culture. Among the immigrants who recently came down from the hills, as among educated sections of the hill people, the Tiwa label and cultural models are gaining momentum. This is the result of a particular kind of reversal. Until recently, plains Tiwa were somehow looked down by the hill people (Hajowali) and designated by Makdoliving, a term meaning "those who have lost their creed". So the formerly peripheral section of the Tiwa, the plains people, escaping their reputation as a de-culturized community, have now become the new reference for Tiwa culture, while the "original" hilly stock is taking on the 
appearance of a backward $\square$ leftover. However, in terms of identity politics, nothing has changed, in the sense that plains and hills people have no doubt that they form a single entity, that they are of the same kind, the main criterion being their recognition of the same kings to which ritual homage is paid every year.

The three Assamese cases that I have too briefly and too roughly sketched, confirm the validity of one of Leach's main assumptions in PSHB: the cohesion of societies cannot be established without, paradoxically, assuming the dissociation of identity, cultural patterns variations and practices. As we have seen, each of these levels is organized according to a specific logic, which does not imply that it is isolated from the other levels. Indeed, the Assamese anthropological landscape shows how the relationships between identity, cultural patterns and practices may be built in very different ways according to places and times. Dimasa combine a very strong identity and strict enrolment rules, both founded on clanic principles, with a flexible system of ritual interactions. Among the Karbi, the flexibility of ritual apparatus is, in contrast, associated with an acceptation of cultural and political variations and a widely declarative identity. Dimasa and Karbi situations would represent two diverging evolutions of an older pattern exemplified by the Lalung-Tiwa, where cultural heterogeneity is second to the political allegiance, which forms the real basis of identity. In certain ways, this old logic is being reversed in the present ethnic politics. Where a group was formerly defined in relation to a paramount entity, a king or a State, now the group is posed a priori and subsequently negotiates its relations with the State $\square$ i.e. India. Members of the group may have different views about the legitimacy of that State and the attitude to be adopted towards it. Some Karbi or Dimasa may acknowledge the present political arrangements, others may ask for a wider autonomy, while others again may reject the sovereignty of the Indian State over their people and ask for independence. In all cases, however, the self-ascribed identity precedes the debate over the political status.

As a matter of fact it is through the permanent invention of original relationships between identity, cultural variations and practices that societies evolve and often regenerate themselves. Obviously, the discourses that people produce about their own society always tend to amalgamate culture, structure and practices into a single perennial essence; such a discourse is not to be thrown away as a mere fiction, it is one of several aspects of social 104 
reality. It is on this particular point that Leach $\varangle$ approach might have to be reconsidered to fit contemporary political situations. In PSHB, Leach did not really speak of identity per se, and he definitely did not speak about identity politics. It is, however, impossible today to avoid what has become a major factor in the shaping of the societies of this region.

Thus, for Leach, the "cultural situation" resulted from "historical incidents" and was only a "dress" of the "social situation" ${ }^{24}$. Whatever objection can be made against this idea, the fact is that today, people rely largely on cultural appearances in their identity building. Cultural differences between groups may have very concrete implications for their political relationships as well as for the relationships inside each group. In present-day Northeast India, identity perceptions are largely shaped by the nineteenth century nation model of "one territory, one history, one language, one culture, one people"; cultural similarities and dissimilarities define spaces that certain groups claim appropriate, and where they try to impose certain types of social relations, certain institutions, certain laws. Through this realization of a culture-based identity model, the correspondence between a social structure and a cultural area may well become a reality. Political unity, whatever its artificiality, may induce a cultural homogeneity when, for example, a scheduled tribe is given autonomy over a particular district where, among other things, a uniform indigenous educational curriculum will be imposed.

The minimization of both cultural differences and ethnic labels was fully legitimate in the $1940 \llbracket$ s to $1950 \llbracket$ s: the deconstruction of colonial categories represented a true progress of knowledge by rendering more correctly the large degree of independence between political structures and cultural forms. Fifty years later, the tools designed by Leach remain largely efficient, on condition that they are reshaped in order to take into account new political contexts, in which the political construction of identities determines a closer dependency between culture and social structures.

1 Among the people who made this fieldwork possible, I'd like to thank more particularly Samiran Boruah in Guwahati, Sarvajit Thaosen, Snigdha Hasnu and A.K. Langthasa in NC Hills, and Kangbura Senar in Diphu. 2 see Baruah, 1985, particularly p. 369 ff.

3 On this notion, see B.K. Roy Burman, 1994, pp. 81-91.

${ }^{4}$ Barua, 1985, p. 86.

5 The court could have included PSHB in the exhibits : because as a matter of fact, daikho is often spelled mdai- 
$k h o$, where mdai means "deity", a term strikingly similar to the Kachin Madai, the chief of the sky spirits which has an altar in the headman's house (Leach, PSHB, p. 136). Kho can mean a "place" or a "container", like the granary, maikho.

6 Danda, 1978, 126-127.

7 ibid.

8 Authors writing on the Tay dodecarchies have noted that the number 12 is purely conventional; cf.

Condominas, 1980, p. 270 and Izikowitz, 1962.

9 Further investigations may precise the exact relationships that the Hedamba State entertained with the Dimasa clans. The Dimasa term for "male clan" is sengphong which literally means "holder of the sword", i.e. sacrificial sword which Dimasa distinguish from the fighting sword, tang. One of the first Dimasa king held his power from the discovery of the sword Ranachandi $\square$ an epithet of the Goddess (Gohain, 1977, pp. 11-12). This let imagine a "clanic state", and a territory which was being partaken among several clans, each with their ritual centre, the daikho. Possible links have also to be explored with the sword hengdān, which the Ahom sovereigns handed down to their dignitaries and vassals (e.g. Bhuyan, 1990, p. 62).

10 cf. Pascal Bouchery, 1988, on the importance of salt in the relationships between the neighbouring Nagas and the Ahom state.

11 Danda, op. cit., p. 126-127.

12 The term "Karbi" does not seem to appear in the Ahom chronicles. It seems that "Mikir" was used instead ; eg. Barua, 1930, p. 285, for a mention in the XVIIIth century.

13 Most villages are referred to by the clan name of their present or former chief, a situation which seems to be peculiar to the Karbi area.

14 Stack, pp. 31, 42.

15 Geertz, 1980.

16 Purification seems to play a central role in these two societies, both at bottom and central levels, with specific functions and meanings compared to the classical Hindu purification. Some clues indicate a possible common background: for instance, the Dimasa thar-, "to purify", might bear some link with the Karbi term kathar, which designates a village priest in Kamrup and the central priest in the lindok area, who is primely considered as the "rains priest".

17 Stack, op. cit., p.23.

18 Gurdon, 1907, pp. 62-63, is the first to have noticed the pluricultural nature of Bhoi. What was generally described as a section of the Khasi included in fact not only Khasi speaking people but also Mikir and Lalung. 19 On the Lalung, cf. Gohain1993.

20 For Ahom testimonies, see Bhuyan, 1933, pp. 160-165. For Jaintiya versions : Shadap Sen, 1981, pp. 130149.

21 Sharmathakur, 1985 , p. 75 .

22 Jonbil mela is also attended by Khasi and Karbi speakers of the area. Further investigations will confirm if they are considered and consider themselves as "subjects" of the Gobha king.

23 On the Tiwa, see Sharmathakur, op. cit.

${ }^{24}$ Leach, 1954, p. 16.

\section{References}

Barua, G.C. Ahom Buranji. From the Earliest Time to the End of Ahom Rule (1st ed. 1930), Guwahati, Spectrum, 1985.

Baruah, SL. A Comprehensive History of Assam, Delhi, Manoharlal, 1985.

Bhattacharjee, J. "Sequences in development in the Barak Valley" in. J.B. Bhattacharjee (ed.), Sequences in development in North East India (a study of tradition, continuity and change) / New Delhi, Omsons, 1989. 
Bhattacharjee, T. Sociology of the Karbis, Delhi, B.R. Pub., 1986.

Bhuyan, S.K. (ed.) Tungkhungia Buranji or the History of Assam (1683-1826 AD), Guwahati, Dept of History and Antiquarian Studies, 1933 (1990).

Bouchery, P. "Les systèmes politiques Naga", Journal Asiatique, 1988, vol.276, n³-4, p. 285-334

Danda, D.G. Among the Dimasa of Assam : an Ethnographic Study, New Delhi, Sterling, 1978.

Condominas, G. L'Espace social à propos de l'Asie du Sud-Est, Paris, Flammarion, 1980.

Geertz, C. Negara: The Theatre State in Nineteenth-Century Bali, Princeton, 1980.

Gohain, B.K. The Hill Lalungs, Guwahati, Anundoram Borooah Inst., 1993.

Hunter, W. A Statistical Account of Assam (2 vol.), Delhi, B.R. Pub, 1879.

Izikowitz, K.G. "Notes about the Tai", Bulletin of Far Eastern Antiquities, 34, 1962, pp. 7391.

Leach, E. Political Systems of Highland Burma: a Study of Kachin Social Structure, Cambridge, Harvard University Press, 1954.

Roy Burman, B.K. Tribes in Perspective, New Delhi, Mittal Pub., 1994.

Shadap Sen, N.C., The Origin and Early History of the Khasi-Synteng People, Calcutta, Firma, 1981.

Sharmathakur, G.C. The Lalung (Tiwas), Guwahati,Tribal Research Institute Assam, 1985.

Stack, E. The Mikirs; from the papers of the late Edward Stack ... edited, arranged and supplemented by Sir Charles Lyall, London, Nutt, 1908. 